 \\ z Filologii Polskiej \\ i Słowiańskiej
}

\section{Przydatność analizy semantycznej i składniowej do badań nad tekstem. Wybrane tytuły w słoweńskich tekstach popularnonaukowych}

Tematem artykułu jest przydatność analizy semantyczno-składniowej do badań nad tekstem. Tak zarysowany cel wpisuje niniejsze opracowanie w wieloletnią tradycję badań tekstologicznych w językoznawstwie slawistycznym i polonistycznym. Ostatnie kilkadziesiąt lat przyniosło rozkwit badań nad tekstem prowadzonych dla rozmaitych celów oraz przy użyciu różnych metodologii i narzędzi badawczych. Przegląd zróżnicowanych badań tekstologicznych odnajdujemy w kompendium Tekstologia (Bartmiński \& Niebrzegowska-Bartmińska, 2009). Wśród klasycznych prac dotyczących zagadnień tekstu w językoznawstwie polskim należy przywołać monografię T. Dobrzyńskiej (Dobrzyńska, 1993), a także uwzględniającą kontekst kulturowy w badaniach nad dyskursem Annę Duszak jako autorkę rozprawy Tekst, dyskurs, komunikacja międzykulturowa (Duszak, 1998). Analiza dyskursu stanowi wciąż aktualny temat badawczy na świecie (van Dijk, 2001; Fairclough, 2003). Lingwiści zajmujący się problematyką dyskursu w Słowenii kierują się także ku zagadnieniom

This is an Open Access article distributed under the terms of the Creative Commons Attribution 3.0 PL License (creativecommons.org/licenses/by/3.0/pl/), which permits redistribution, commercial and non-commercial, provided that the article is properly cited. () The Author(s) 2016. 
szczegółowym (Mikolič, 2007; Vičar, 2011). W kręgu zainteresowań badaczy słoweńskich pozostają także teksty popularnonaukowe (Pisanski-Peterlin, 2015).

Ostatnie kilkadziesiąt lat w lingwistyce to także dynamiczny rozwój badań składniowych. W Polsce rozwinęła się szkoła składni semantycznej (Karolak, 1984, 2002). Autor tej koncepcji zainspirował do prowadzonych w podobny sposób lub nawiązujących do jego studiów analiz badaczy w różnych ośrodkach w krajach słowiańskich. Metodologia ta była twórczo wykorzystywana w wielu badaniach porównawczych. Podjęte prace zaowocowały międzynarodowymi projektami oraz publikacjami (Kiklewicz \& Korytkowska, 2010). W Słowenii lingwistka specjalizująca się w semantyce i składni czasowników słoweńskich, zwłaszcza w aspekcie ich łączliwości (Žele, 2008), wydała podręcznik akademicki pod znamiennym tytułem Slovenska besedilna skladnja z jezikovnosistemskega vidika - temeljni pojmi (Słoweńska składnia tekstu w powiązaniu z systemem języka. Kluczowe pojęcia) (Žele, 2013).

W artykule pragnę pokazać na wybranych przykładach rolę analiz semantyczno-składniowych tytułów dla zrozumienia ustrukturyzowania treści danej jednostki tekstu, a także uzasadnienie wyboru strategii formalizacji danego tytułu dla interpretacji analizowanego fragmentu.

Tytuł traktuję jako bardzo ważny, strategiczny składnik dyskursu. Badaniem dyskursu od lat zajmuje się grupa badaczy kształtujących obraz omawianej dziedziny i związaną z nią terminologię w językoznawstwie polskim (S. Gajda, 1999; Starzec, 1999; Duszak, 1998). Warto przytoczyć definicję dyskursu podaną przez Romualdę Piętkową za Kawką: „ciąg zachowań językowych, których postać zależy od tego, kto mówi, do kogo, w jakiej sytuacji i w jakim celu. Tak pojęty dyskurs jest rodzajem interakcji społecznej dokonującej się przy udziale języka. W związku z tym poszukiwanie reguł dyskursu musi obejmować poziom zjawisk psychofizycznych, poziom zjawisk społecznych i wreszcie poziom języka jako systemu semiotycznego rządzącego się własnymi prawami” (Kawka, 1999, s. 13; Piętkowa, 2004, s. 119). Podtrzymuję tezę, że tak szeroka definicja dyskursu pozwala na stosowanie jej do badań nad szczególnym typem tekstów, jakie wpisują się w dyskurs naukowy (Piętkowa, 2004, s. 119). Tytuł jest rodzajem paratekstu. Spełnia wobec danego tekstu funkcję reprezentacyjną (Piętkowa, 2004, s. 121). W przywoływanym artykule Romualda Piętkowa podkreśla jakościowe zmiany dokonujące się w tytułach tekstów naukowych. Lingwistka zauważa, że przy zachowaniu funkcji informacyjnej, odniesienia do zawartości treściowej, tytuły tekstów naukowych coraz częściej przyjmują także funkcje pragmatyczne, charakteryzują się swoistą atrakcyjnością, i zaczynają 
przez to przypominać slogany reklamowe (Piętkowa, 2004). Badacze tytułów wskazują na ich różne typy i funkcje, jak informacyjna, wartościująca, ideowa (Stoff, 1975; Uździcka, 2007). Na potrzeby niniejszego opracowania warto przyjrzeć się relacjom między tytułem a opatrzonym przez ów tytuł tekstem. Tytuł zajmuje inicjalną pozycję $\mathrm{w}$ tekście i pozycja ta przyczynia się do pełnienia przez tytuł funkcji organizującej, orientującej. Tytuł zapowiada treść danego segmentu tekstu (Duszak, 1998, s. 129).

Metoda konfrontacji analizy semantyczno-składniowej paratekstu, czyli tytułu, z treścią danego fragmentu była już uprzednio przedmiotem studiów (Zatorska, 2013). Aparat składni semantycznej zastosowany do analizy budowy i funkcji wybranych tytułów pozwolił na szereg obserwacji pogłębiających interpretację i analizę rozpatrywanego tekstu globalnego. W paralelnym studium wykorzystującym analizę funkcji tytułów obok innych aspektów tegoż tekstu wyprowadzono wnioski o charakterze genologicznym (A. Gajda, 2013).

Tę dość oczywistą tezę o związku między tytułem - czy raczej jego językową formalizacją - a zawartością danego akapitu przedstawiam na przykładach zaczerpniętych ze słoweńskich tekstów popularnonaukowych dotyczących dziejów Słowenii (Prunk, 2002; Vodopivec, 2003; Granda, 2008). Wszystkie trzy publikacje ukazują w przystępnej formie zarys historii terytorium Słowenii od początku osadnictwa na tym terenie aż do współczesności. Są zatem przykładami tekstów z obszaru dyskursu popularnonaukowego. Styl i funkcje popularnonaukowe osiągane są w omawianych makrotekstach za pomocą rozmaitych strategii. Jedną z nich jest nawiązanie dialogu ze współczesnym czytelnikiem przez wprowadzenie do tematyki wybranego fragmentu poprzez inwersję czasową i sięgnięcie do współczesności, do doświadczenia czytelnika. W podrozdziale Pod Kelti Stane Granda przytacza dla uzasadnienia tezy o celtyckich przodkach części populacji dzisiejszych Słoweńców choć, jak zaznacza, świadomość tego dziedzictwa jest niewielka „malokdo pa se sklicuje na Kelte” (Granda, 2008, s. 31) - rozmowę lekarza dermatologa z pacjentką o wyjątkowo jasnej, wrażliwej cerze, cytując słowa lekarza: „Draga moja, morali se boste sprijazniti s to občutljivostjo. Nisem kriv, če ste Keltinja" (Granda, 2008, s. 31) („Moja droga, będzie się pani musiała przyzwyczaić do tej nadwrażliwości. Nie jest to moja wina, że pani ma celtyckie pochodzenie") ${ }^{1}$. Drugim zabiegiem stosowanym w badanych tekstach jest wplatanie fragmentów autotematycznych, wewnętrznego monologu historyka, czy też dialogu z ewentualnymi oponentami

\footnotetext{
1 Tłumaczenie własne A. Z.
} 
czy dyskutantami. Wprowadzane strategie mają na celu przybliżenie specjalistycznej wiedzy niespecjalistom i są charakterystycznymi sygnałami odmiany popularnonaukowej stylu naukowego.

Przedmiotem moich badań jest 110 wybranych tytułów rozdziałów i podrozdziałów pochodzących z wymienionych źródeł. W zarysie Grandy są to śródtytuły podrzędne w stosunku do tytułów rozdziałów, czyli tytuły podrozdziałów (Granda, 2008), por. tytuł rozdziału Zgodovina ozemlja pred naselitvijo, tytuł podrozdziału to Govorica arheologije (Granda, 2008, s. 19). Relacja tytułów i śródtytułów jest również w omawianych tekstach wskaźnikiem spójności, sygnalizuje także hierarchiczną strukturę tekstu (Duszak, 1998, s. 131). Formalna klasyfikacja językowa pozwala wyróżnić tytuły o postaci grup nominalnych i werbalnych. W badanym materiale znaczną grupę stanowią tytuły zawierające rzeczowniki wraz z określającymi je przymiotnikami (ok. 15\%), por. Halštatska kultura GR. Często grupa nominalna występuje w liczbie mnogiej Ilirske province, Obmejne krajine, Zemljiškji gospodje GR. Przymiotniki mogą występować szeregowo, np. Naporno zahodno sosedstvo GR; Nemški državni okvir SZBS. Rzadziej w funkcji tytułu użyto pojedynczego wyrazu rzeczownikowego, często także w pluralu, np. Dežele GR; Gradovi GR; Karantanci GR. Wśród tytułów znalazły się imiona własne, por. Marija Terezija GR; Jožef II GR. Odnotowano także wyrażenia przyimkowe, np. Pod Kelti GR, lub frazy zawierające rozbudowane wyrażenia, por. Ozemlje Slovenije $v$ antiki PR. Porównując egzemplifikację tytułów badanych trzech książek popularnonaukowym, dostrzegam, że tytuły u Prunka charakteryzują się większą eksplicytnością, są bardziej dookreślone. Wyrazista jest zatem ich funkcja informacyjna, np. Etnična prevlada Slovanov in njihova država Karantanija PR, por. paralelny tytuł u Grandy: Karantanci GR.

Śródtytuły w historii Słowenii autorstwa Stanego Grandy charakteryzuje lapidarność i elegancja, choć osiągnięto to czasem kosztem zawartości informacyjnej paratekstu. Tytuły Janka Prunka, np. Marčna revolucija 1848. Rojstvo programa Zedinjena Slovenija, same niosą już pełen ładunek informacyjny, streszczający zawartość danego podrozdziału, odznaczają się zatem wysoką eksplicytnością, często wyższą niż paralelne tytuły u Grandy, por. Revolucionarno leto 1848 GR. Uzupełnienie przez Prunka tytułu odnoszącego się do rewolucji marcowej poprzez dopowiedzenie Rojstvo programa Zedinjena Slovenija PR jest słusznym zabiegiem pozwalającym na identyfikację faktów historycznych już na poziomie ramy tytułu. Prowadzone obserwacje potwierdzają tezę, że „tytuły oscylują między czysto hasłowym sygnalizowaniem treści 
a rekonstrukcją całego schematu podstawowych związków semantycznych leżących u podstaw tekstu" (Duszak, 1998, s. 131).

Wśród składników badanych tytułów znaczącą grupę (ok. 50\%) stanowią te, które kwalifikuję jako nominalizacje, czyli nominalne wykładniki predykatów. Do nominalizacji zaliczam rzeczowniki zdarzeniowe, które odpowiadają treści propozycjonalnej, np. boj, razvoj, rojstvo. Z tego zbioru można wyabstrahować wyrazy kwalifikowane przez gramatyki słoweńskie i SSKJ jako nominalizacje właściwe słoweń. glagolnik, np. izbruh, modernizacija, odcepitev, okupacija, osamosvojitev, razmah, utrjevanje etc. Do nominalizacji w węższym sensie należy ok. 25\% badanych tytułów.

Tytułom zawierającym w swej formalnej strukturze frazy o postaci nominalizacji (w szerszym sensie) pragnę poświęcić w niniejszym artykule nieco więcej uwagi. Nominalizacje jako podstawa tytułów stanowią obiecujące pole eksploracji ze względu na właściwości semantyczno-składniowe ujawniane przy transpozycji treści predykatywnej w nomen, cechy znane i opisywane w literaturze przedmiotu jak większa ogólność komunikatu, możliwość neutralizacji pewnych pozycji argumentowych oraz innych elementów semantycznych, jak wykładniki temporalne (Tokarz, 1987; Jędrzejko, 1993; Korytkowska \& Małdżiewa, 2002). Teksty historyczne poświęcone Słowenii były już podstawą badań nad fenomenem nominalizacji, a przeprowadzona kwerenda potwierdziła hipotezę o dużej frekwencji wyrażeń nominalnych służących ukazywaniu treści predykatywnych w tekstach poświęconych zagadnieniom historycznym (Zatorska \& Gojkošek, 2013; Zatorska, 2015).

Przykładowe tytuły $\mathrm{z}$ materiału dobranego na potrzeby obecnego opracowania wpisują się w szereg zjawisk semantyczno-składniowych charakterystycznych dla fraz z nominalnymi wykładnikami predykatów. Na wybranych przykładach spróbuję udowodnić tezę o przydatności badań semantyczno-składniowych do interpretacji badanych struktur tekstowych.

Analizowany materiał potwierdza tezę o większych możliwościach w zakresie nieujawniania potencjalnych argumentów przy nominalizacjach jako wykładnikach wewnętrznych predykatów niż przy wyrażaniu owych predykacji przez verba (Korytkowska \& Małdżiewa, 2002, s. 19). Na potencjał konstrukcji $\mathrm{z}$ nominalizacjami w zakresie nieujawniania wybranych elementów struktur semantycznych, na przykład fraz $z$ argumentem w pozycji agentywnej, i implikacje takiej strategii dla wymowy tekstu wskazywali już uprzednio inni badacze (Fowler, 1991, s. 80). Tytuł Naselitev in prilagajanje zahodni civilizaciji in kulturi wskazuje na makrostrukturę komunikatu, a jednocześnie przy zastosowaniu 
odczasownikowego nomen naselitev jest frazą z niewyrażonym argumentem osobowym. Ukrycie argumentu/argumentów sprawia, że tytuł ma charakter otwarty, intrygujący. Prawdopodobnie struktura z niewypełnionymi miejscami argumentowymi została użyta celowo wobec zawartości treściowej podrozdziału, który traktuje o najdawniejszej historii obecności Słowian na terenie dzisiejszej Słowenii i wskazuje na skomplikowane relacje etniczne na omawianych terenach jeszcze przed utworzeniem księstwa Karantanii (por. Karantanci GR). W bogato ilustrowanej historii Słowenii pod red. Barbary Vodopivec SZBS omawiany okres dziejowy opatrzony został tytułem o postaci nominalizacji $\mathrm{z}$ wypełnioną argumentową pozycją agentywną oraz z wyrażonym argumentem przedmiotowym w pozycji lokatywnej, por. Naselitev Slovanov $v$ Vzhodne Alpe SZBS, z nomen actionis naselitev utworzonym od czasownika naseliti (se). W tytule podrozdziału u Grandy uwypuklona została adaptacja do zachodniej cywilizacji, u Vodopivec spotykamy expressis verbis wyrażonego aktanta, agensa przy nominalnym wykładniki predykacji Naselitev Slovanov... SZBS. Janko Prunk dla omawianego okresu w dziejach Słowenii zastosował tytuły uszczegółowione, z wysoką eksplikatywnością: Etnična prevlada Slovanov in njihova država Karantanija PR oraz Propad samostojne Karantanije PR. Drugi z wymienionych tytułów u Prunka jest paratekstem zarazem pełnym i otwartym. Pozycja argumentowa przy nominalnej realizacji predykatu jest wypełniona, jednakże dopiero lektura fragmentu wyjaśnia uwarunkowania słowiańskiej „państwowości” w Karantanii i Karniolii. Przykładem tytułu o postaci nominalizacji z niezrealizowaną potencjalną pozycją argumentową jest Ustoličevanje knezov GR. W tytule podrozdziału w centralnej pozycji autor umieszcza informację o średniowiecznym obrzędzie przekazywania władzy na specjalnym kamieniu, spodniej części dawnej kolumny rzymskiej (Granda, 2008, s. 58), a jako jeden $z$ kluczowych wyrazów w omawianym fragmencie pojawia się knežji kamen. Dopiero zawartość podrozdziału przynosi wyjaśnienie zagadki sugerowanej przez tytuł, w którym brakuje informacji, kto dokonywał tego obrzędu.

Zorenje in izbruh reformacije SZBS uznaję za przykład trafnego tytułu. Zawarte są w nim dwie nominalizacje: zorenje i izbruh. Obie odnoszą się do okresu, a zarazem procesu i faktu religijno-kulturowego, jakim była reformacija. Tytuł spina metaforyczną klamrą wydarzenia związane z początkiem i rozwojem ruchu protestanckiego na ziemiach przyszłej Słowenii. W tytule użyto rzeczowników, których semantyka odsyła do zdarzeń dynamicznych, zwłaszcza izbruh 'wybuch, erupcja' w budowie semantycznej zawiera sem 
zdarzenia charakteryzującego się dynamicznością i gwałtownością, dużą intensywnością. Tak skonstruowany tytuł świetnie wypełnia funkcję, jaką badacze tekstu wyznaczają paratekstom: „oddziaływanie perswazyjne na czytelnika - przykucie jego uwagi” (Piętkowa, 2004, s. 126).

Warto podkreślić, że uzupełnienie treściowe bywa w badanym materiale domeną drugiej części analizowanego tytułu. Druga partia rozpatrywanego paratekstu odsyła do zawartości treściowej omawianego komunikatu, np. Prva svetovna vojna. Odcepitev Slovencev od Avstrije PR. Konwencja ta potwierdza obserwacje badaczy dyskursu, według których często druga część tytułu informuje o globalnym znaczeniu tekstu (Piętkowa, 2004, s. 126). Wyraźna informacja o delimitacji tekstu obecna może być także w dwuczłonowym tytule szeregowym, por. Posvetno in cerkveno življenje SZBS. Odpowiedni fragment książki pod redakcją Barbary Vodopivec, podobnie jak tytuł, charakteryzuje się dwudzielną budową, jednakże jego lektura przynosi pewien niedosyt, gdyż fragment opowiada przede wszystkim o rozwoju administracyjnym i gospodarczym - sfera religijna, funkcjonowanie organizacji kościelnej są tylko zasygnalizowane. Lukę tę zapełnia monografia Grandy, który oddziaływaniu Kościoła w na historię Słowenii poświęcą wiele wersów, czego dowodem są również tytuły, por. Začetki krščanstva na današnjem slovenskem ozemlju GR; Pokristjanjevanje Slovencev GR; Cerkvena ureditev GR; Delo solunskih bratov Cirila in Metoda GR. W książce Prunka znajdujemy rozbudowane tytuły szeregowe z rozwinięciami (najczęściej adiektywnymi) w ramach grupy nominalnej, por. Politično življenje v jugoslovanski kraljevini; Razmah delavskega in družbenega samoupravljanja; Kriza samoupravljanja in mednarodnih odnosov $v$ Jugoslaviji PR. Wyliczanie elementów frazy nominalnej poświadczają również śródtytuły z pozostałych źródeł: Industrijska in kulturna modernizacija SZBS. Układ kaskadowy lub szeregowy obserwuje się także przy tytułach zawierających nominalizacje. Także nomina actionis mogą występować szeregowo połączone spójnikiem: Nastanek demokratične opozicije in njena zmaga na volitvah; Razpadanje Jugoslavije in osamosvojitev Slovenije PR. Podane przykłady ilustrują kondensację treści przez zestawienie więcej niż jednej predykacji ${ }^{2}$. Takie ustrukturyzowanie komunikatu w tytule potwierdza

2 Tematem oddzielnych badań może być wewnętrzna struktura złożonych fraz nominalnych, a także szeregów tychże. Semantyka poszczególnych członów nominalnych wywiedzionych ze struktur predykatowo-argumentowych może wskazywać na wynikanie, a także na inne relacje, na przykład temporalne. 
syntaktyczny proces, jakim jest transforma zdania złożonego w rozwinięte zdanie pojedyncze (Korytkowska \& Małdżiewa, 2002).

Przy omawianiu funkcjonowania nominalizacji w tekstach porusza się nie tylko kwestię niewyrażania potencjalnych elementów struktury semantycznej, ale także sposoby ujawniania tychże. Już we wcześniejszych publikacjach pisano o tendencji do wyrażania argumentów przedmiotowych przy nominalnych wykładnikach predykacji w języku słoweńskim w postaci przymiotników (Tokarz, 1987; Zatorska \& Gojkošek, 2013; Zatorska, 2015). Zjawisko to poświadczone jest także w analizowanych przykładach, por. Kmečki upori GR; Madžarski vpadi GR; Turški vpadi GR. Użycie przymiotników relacyjnych kryje skomplikowane odniesienia semantyczne wnoszone przez frazę z nominalnym wyrażeniem predykacji, por. Protifašistični in revolucionarni boj SZBS. W przykładzie tym brak wykładników argumentów przedmiotowych dla oznaczenia osób lub zbiorowości „toczących bój”. Charakterystyka dokonana przez przymiotniki relacyjne jedynie sygnalizuje bardzo skondensowane i ukryte struktury sensu (w tym presupozycje) znajdujące się u podstaw zastosowanego wyrażenia.

Zgodnie z oczekiwaniami w materiale znalazły się także tytuły o strukturze eliptycznej, np. Od vidovdanske ustave do kraljeve diktature SZBS.

Podsumowując, można powiedzieć, że analiza tytułów i śródtytułów w trzech popularnonaukowych publikacjach o historii Słowenii potwierdza tezę o strategicznym znaczeniu tekstu inicjalnego, jakim jest tytuł, i jego znaczeniu dla dyskursu popularnonaukowego oraz dla podjętej komunikacji. Szczególnie interesujące okazały się liczne tytuły zawierające w swej budowie nominalizacje. Tak skonstruowane tytuły mają w sobie potencjał właściwy konstrukcjom znominalizowanym: zdolność do uogólnienia, neutralizacji wybranych elementów. Charakteryzuje je kondensacja treści i dynamika.

Bibliografia

Bartmiński, J., \& Niebrzegowska-Bartmińska, S. (2009). Tekstologia. Warszawa: Wydawnictwo Naukowe PWN.

Dobrzyńska, T. (1993). Tekst: Próba syntezy. Warszawa: Wydawnictwo IBL.

Duszak, A. (1998). Tekst, dyskurs, komunikacja międzykulturowa. Warszawa: Wydawnictwo Naukowe PWN. 
Agnieszka Zatorska Przydatność analizy semantycznej i składniowej do badań nad tekstem...

Fairclough, N. (2003). Analysing discourse. London: Routledge.

Fowler, R. (1991). Language in the news: Discourse and ideology in the press. London: Routledge Gajda, A. (2013). Przewodnik turystyczny czy przewodnik historyczny? - analiza modelu „Przewodnika po powstańczej Warszawie”. Folia Linguistica, 47, 7-19.

Gajda, S. (1999). Współczesny polski dyskurs naukowy. W: S. Gajda (Red.), Dyskurs naukowytradycja i zmiana. Opole: Uniwersytet Opolski, Instytut Filologii Polskiej.

Granda, S. (2008). Mala zgodovina Slovenije [GR]. Celje: Celjska Mohorjeva Družba.

Jędrzejko, E. (1993). Nominalizacje w systemie i w tekstach współczesnej polszczyzny. Katowice: Uniwersytet Śląski.

Karolak, S. (1984). Składnia wyrażeń predykatywnych. W: Z. Topolińska (Red.), Gramatyka współczesnego języka polskiego: Składnia. Warszawa: PWN.

Karolak, S. (2002). Podstawowe struktury składniowe języka polskiego. Warszawa: SOW.

Kawka, M. (1999). Dyskurs szkolny: Zagadnienia języka. Kraków: Wydawnictwo Naukowe WSP.

Kiklewicz, A., \& Korytkowska, M. (Red.). (2010). Podstawowe struktury zdaniowe współczesnych języków słowiańskich: białoruski, bułgarski i polski. Olsztyn: Centrum Badań Europy Wschodniej Uniwersytetu Warmińsko-Mazurskiego.

Korytkowska, M. (1992). Typy pozycji predykatowo-argumentowych. Gramatyka konfrontatywna bułgarsko-polska (T. 5, Cz. 1). Warszawa: SOW.

Korytkowska, M., \& Małdżiewa, W. (2002). Od zdania złożonego do zdania pojedynczego (Nominalizacja argumentu propozycjonalnego w języku polskim i bułgarskim). Toruń: Wydawnictwo Uniwersytetu Mikołaja Kopernika

Mikolič, V. (2007). Modifikacija podstave in argumentacijska struktura besedilnih vrst. Slavistična revija, 55(1/2), 341-355.

Piętkowa, R. (2004). Paratekstualność w dyskursie naukowym. W: M. Ruszkowski (Red.), Wielojęzyczność w perspektywie stylistyki i poetyki (ss. 119-134). Kielce: Wydawnictwo AŚ.

Pisanski-Peterlin, A. (2015). So prevedena poljudnoznvstvena besedila v slovenščini drugačna od izvirnih? Korpusna študija na primeru izražanja epistemske naklonskosti. Slavistična revija, 63(1), 29-43.

Prunk, J. (2002). Kratka zgodovina Slovenije [PR]. Ljubljana: Založba Grad.

Slovar slovenskega knjižnega jezika [SSKJ]. (2000). (Elektronska izdaja, SAZU in ZRC SAZU, Inštitut za slovenski jezik Frana Ramovša in avtorji). Ljubljana: SAZU in ZRC SAZU.

Starzec, A. (1991). Sugestywność tytułów tekstów popularnonaukowych. W: Wariancje w języku: III Opolskie Spotkanie Językoznawcze, Szczedrzyk 10-11.10.1989 r. (ss. 255-258). Opole: Wydawnictwo WSP w Opolu.

Starzec, A. (1999). Współczesna polszczyzna popularnonaukowa. Opole: Wydawnictwo Uniwersytetu Opolskiego.

Stoff, A. (1975). Funkcja tytułu w dziele literackim. Acta Universatis Nicolai Copernici, (66), 6-11.

Tokarz, E. (1987). Nomina actionis we współczesnym języku słoweńskim. Katowice: UŚ. 
Agnieszka Zatorska Przydatność analizy semantycznej i składniowej do badań nad tekstem...

Uździcka, M. (2007). Tytuł utworu literackiego: Studium lingwistyczne. Zielona Góra: Oficyna Wydawnicza Uniwersytetu Zielonogórskiego.

van Dijk, T. (Red.). (2001). Dyskurs jako struktura i proces. (G. Grochowski, Tłum.). Warszawa: Wydawnictwo Naukowe PWN SA.

Vičar, B. (2011). Moralna vrednost živali v diskursu biotske razvrstnosti. W: S. Kranjc (Red.), Meddisciplinarnost $v$ slovenistiki: Interdisciplinary in Slovene studies (ss. 509-514). Ljubljana: Znavstvena založba Filozofske fakultete Univerze v Ljubljani. (OBDOBJA, 30).

Vodopivec, B. (Red.). (2003). Slovenska zgodovina v besedi in sliki [SZBS]. Ljubljana: Založba Mladinska knjiga.

Zatorska, A. (2013). „Bitwa o każdy grób”: Semantyczno-składniowa oraz funkcjonalna analiza tytułów w „Przewodniku po powstańczej Warszawie”. Folia Linguistica, 47, 20-33.

Zatorska, A. (2015). Rola nominalizacji w polskich oraz słoweńskich opisach i relacjach z pierwszej wojny światowej. W: J. Getka, J. Grzybowski, \& R. Kramar (Red.), Wojna w Europie Srodkowo-Wschodniej z perspektywy interdyscyplinarnej (ss. 185-197). Warszawa: Uniwersytet Warszawski.

Zatorska, A., \& Gojkošek, M. (2013). Nominalizacije in njihova funkcijskost v besedilih o zgodovini Slovenije. W: Družbena funkcijskost jezika (vidiki, merila, opredelitve) (ss. 497-502). Ljubljana: Znavstvena založba Filozofske fakultete Univerze v Ljubljani. (OBDOBJA 32).

Žele, A. (2008). Vezljivostni slovar slovenskih glagolov. Ljubljana: SAZU in ZRC SAZU.

Žele, A. (2013). Slovenska besedilna skladnja z jezikovnosistemskega vidika - temeljni pojmi: Učbenik. Ljubljana: samozal.

Żydek-Bednarczuk, U. (2003). Strategie językowe w tytułach dyskursów naukowych. W: J. Sobczykowa (Red.), Śląskie studia lingwistyczne (ss. 217-226). Katowice: Wydawnictwo Uniwersytetu Śląskiego.

\section{Źródła}

GR - Granda S. (2008). Mala zgodovina Slovenije. Celje: Celjska Mohorjeva Družba.

PR - Prunk J. (2002). Kratka zgodovina Slovenije. Ljubljana: Založba Grad.

SZBS - Vodopivec B., (red.). (2003). Slovenska zgodovina v besedi in sliki. Ljubljana: Založba Mladinska knjiga.

SSKJ - Slovar slovenskega knjižnega jezika. (2000). Elektronska izdaja. Ljubljana: Inštitut za slovenski jezik Frana Ramovša ZRC SAZU. 


\section{The usefulness of semantic and syntax analysis in discourse analysis. Chosen titles in Slovene popular science texts}

\section{Summary}

The article is devoted to chosen titles and subtitles in Slovene-language popular science texts about Slovene history. The data comprise 110 examples taken from the three Slovene popular science books. The analysed phrases have different forms (nouns, adjective-modified nouns, nominalizations). The conducted study is methodologically based on semantic and syntax analysis - the analysis of the ways of realization of the predicate-argument structure on which a given initial para-text is founded - as applied in the context of textual analysis of scientific, and especially popular scientific, discourse. The author of the article investigates the relation between the given title and the content of the corresponding portion of the macro-text. Particularly interesting are titles formed by means of nominalization, that is to say - by means of a transformation of predicate-argument structure. When used as titles, nominalizations confirm their expected semantic and syntax features, such as the capacity for the omission of chosen elements, increased generality and the same time compactness of the message. They also proved fruitful elements of the strategies of macro-text construction based on using appropriate titles. 


\section{Przydatność analizy semantycznej i składniowej do badań nad tekstem. Wybrane tytuły w słoweńskich tekstach popularnonaukowych}

\section{Streszczenie}

Artykuł dotyczy wybranych tytułów rozdziałów i podrozdziałów w książkach popularnonaukowych o historii Słowenii. Materiał obejmuje 110 przykładów z języka słoweńskiego o zróżnicowanej postaci - rzeczowników, rzeczowników modyfikowanych przez przymiotniki, wyrażeń przyimkowych. Podjęte badania wpisują się w analizę semantyczno-składniową, czyli analizę sposobów realizacji potencjalnej struktury predykatowo-argumentowej fundującej dany paratekst inicjalny, w kontekście badań nad tekstem, zwłaszcza w ramach dyskursu naukowego w odmianie popularnonaukowej. Analizie poddano relację między tytułem a opatrzonym przez ten tytuł fragmentem makrotekstu. Szczególnie interesujące okazały się tytuły będące nominalizacjami, czyli transformacjami struktur predykatowo-argumentowych. Frazy o postaci nominalizacji w tytułach potwierdziły standardowe obserwacje semantyczno-składniowe łączone zwykle z transpozycją w nomen (możliwość redukcji wybranych składników, większą ogólność, a zarazem kondensację przekazu). Okazały się także owocne w strategiach budujących makrotekst poprzez użycie odpowiedniego tytułu.

Keywords: Slovene language; semantics; syntax; titles; popular science discourse

Słowa kluczowe: język słoweński; semantyka; składnia; tytuły; dyskurs popularnonaukowy

Agnieszka Zatorska, Department of Slavic Studies, Faculty of Philology, University of Lodz, Łódź

Correspondence: Uniwersytet Łódzki, Wydział Filologiczny, Katedra Filologii Słowiańskiej, ul. Pomorska 171/173, 90-236 Łódź, Poland; Agnieszka.Zatorska@uni.lodz.pl

The work was self-funded by the author.

Competing interests: The author has declared she has no competing interests. 